\title{
RNF217-AS1 wt Allele
}

National Cancer Institute

\section{Source}

National Cancer Institute. RNF217-AS1 wt Allele. NCI Thesaurus. Code C97904.

Human RNF217-AS1 wild-type allele is located in the vicinity of $6 q 22.33$ and is approximately $55 \mathrm{~kb}$ in length. This allele, which encodes six-twelve leukemia non-coding RNA, is involved in a translocation $\mathrm{t}(6 ; 12)(\mathrm{q} 23 ; \mathrm{p} 13)$ with the ETV6 gene that is associated with B-cell acute lymphoblastic leukemia. 